\title{
The Importance of Computerized Drug Interaction Checker Programs Used in Community Pharmacies to Avoid Potential Drug Interactions: A Preliminary Study with Clarithromycin
}

\author{
Potansiyel İlaç Etkileșimlerinin Önlenmesinde Serbest Eczanelerde Kullanılan Bilgisayarlı \\ İlaç Etkileşimi Kontrol Programlarının Önemi: Klaritromisin ile Yapılan Bir Ön Çalıșma
}

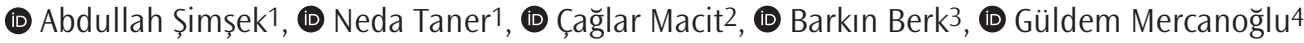 \\ 1 isstanbul Medipol University Faculty of Pharmacy, Department of Clinical Pharmacy, İstanbul, Turkey \\ 2istanbul Medipol University Faculty of Pharmacy, Department of Pharmacology, İstanbul, Turkey \\ 3istanbul Medipol University Faculty of Pharmacy, Department of Pharmaceutical Chemistry İstanbul, Turkey \\ 4University of Heath Sciences Faculty of Pharmacy, Department of Pharmacology, İstanbul, Turkey
}

\begin{abstract}
Introduction: Drug-drug interactions (DDI) due to multiple drug use are the most important cause of adverse drug reactions. DDIs are among medication errors that can be prevented. The integrated computerized drug interaction checker programs, which medical professionals use in addition to their medical and practical knowledge, can help medical staff to reduce potential DDIs (PDDIs), although they are not sufficient alone. The aim of this study was to investigate the role of computerized drug interaction checker programs in the identification and prevention of PDDIs in clarithromycin prescribed pediatric outpatients.
\end{abstract}

Methods: The study was a retrospective observational prescription analysis held in three community pharmacies operating in the province of Üsküdar-istanbul during 12-month period. The prescriptions with oral clarithromycin medication were selected and PDDIs were analyzed using the R $\mathrm{R}_{\mathrm{x}}$ MediaPharma ${ }^{\circledR}$ software on an active substance base.

Results: During the 12-month period, 100 prescriptions containing 266 medicines were prescribed by 52 different physicians. The mean number of medicines per prescription was 2.66 \pm 1.11 . Of the 16 PDDIs detected, five were clarithromycinrelated (31.25\%) and 11 were non-clarithromycin-related (68.75\%). When PDDIs were categorized by severity, 10 out of 16 (62.5\%) were high-risk, two (12.5\%) were moderate and four (25\%) were low-risk. Clarithromycin interactions were moderate with lidocaine and low with both metronidazole and sultamicillin (ampicillin/sulbactam).

Conclusion: Although evidence based computerized drug interaction checker programs that provide rapid access is not sufficient alone, they can help health care professionals in preventing PDDIs. The use of this program in the community pharmacies could minimize PDDIs during the dispensing of medicine.

Keywords: Adverse drug reactions, computerized drug interaction checker program, drug interactions

\section{öZ}

Amaç: Çoklu ilaç kullanımına bağlı olarak gelişen ilaç-ilaç etkileşimleri (DDI) advers ilaç reaksiyonlarının en önemli nedenidir. Ilaç hatalarından bir tanesi olarak sayılan DDI önlenebilir. Sağlık profesyonellerinin tıbbi ve pratik bilgilerinin yanında kullanacakları entegre bilgisayarlı ilaç etkileșimi kontrol sistemleri, tek başlarına yeterli olmamakla beraber olası etkileșimlerin azaltılması için sağıı personeline yardımcı olabilir. Bu çalıșmada ayaktan pediatri hastalarına reçete edilen klaritromisin ile potansiyel DDI'ların (PDDI) belirlenmesi ve önlenmesinde bilgisayarlı ilaç etkileșimi kontrol sistemlerinin rolünün araştırııması amaçlanmışııı.

Yöntemler: Retrospektif gözlemsel reçete analizi niteliğinde olan bu çalıșmada, 12 aylık periyotta (Ocak-Aralık 2016) pediatrik ayaktan hastalara solunum yolu enfeksiyonu tanısı ile oral klaritromisin yazılan reçeteler İstanbul ili Üsküdar ilçesinde faaliyet gösteren ve çalışmaya katılmayı kabul eden, üç serbest eczaneden toplanarak müstahzar isim ve sayıları ile hasta demografik verileri (yaş, cinsiyet) kayıt edildi. PDDI'lar etkin madde bazında $\mathrm{R}_{\mathrm{X}}$ MediaPharma ${ }^{\circledR}$ programı ile tespit analiz edildi.

Bulgular: On iki aylık periyotta 52 farklı hekim tarafından 266 adet müstahzarın reçetelendiği 100 adet reçete toplanmış

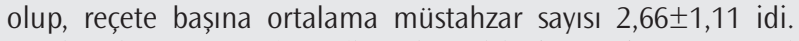
Tespit edilen 16 PDDI'nın 5'i klaritromisin $(\% 31,25)$ ve 11 tanesi klaritromisin dıș (\%68,75) idi. PDDI'lar șiddet bazında kategorize edildiğinde, toplam 16 etkileșimden 10 tanesi $(\% 62,5)$ yüksek, 2 tanesi $(\% 12,5)$ orta ve 4 'ü (\%25) düşük idi. Klaritromisin etkileșimleri ise: Lidokain ile orta; metronidazol ve sultamisin (ampisilin/sulbaktam) ile ise minör kategorisinde idi.

Sonuç: Hızlı erişim imkanı sağlayan bilgisayarlı ilaç etkileşimi kontrol sistemleri tek başlarına yeterli olmamakla beraber PDDI'ların önlenmesinde sağlık personeline yardımcı olabilir. $\mathrm{Bu}$ sistemlerin serbest eczanelerde kullanımı ilacın hastaya verilmesi esnasında yaşanacak olan DDI'ların önlenmesinde oldukça önem taşımaktadır.

Anahtar Kelimeler: Ilaç etkileşimi, bilgisayarlı ilaç etkileşimi kontrol programı, advers ilaç reaksiyonları 


\section{Introduction}

Although there is no definite consensus on its definition, polypharmacy is basically defined as the use of multiple drugs at the same time for more than one indication (1). The main problem with multi-drug use is drug-drug interactions (DDIs). DDIs can be described as a change in the effect of a drug when used in combination with another drug. DDIs may cause an increase or decrease both in the effectiveness and efficacy of the drugs used together, or it may lead to the development of adverse drug reactions (ADRs) (2). Studies show that DDIs account for 3 to $5 \%$ of treatment errors in the hospitals. ADRs as a result of DDIs have been reported as the main cause of hospitalizations with rates of $10-20 \%$ (3), and between the fourth and sixth leading cause of death in hospitalized patients (4). It is, therefore, important to prevent harmful potential DDIs (PDDIs) to prevent drug-related morbidity and mortality and to ensure drug safety during outpatient treatment.

Among drug medications, DDIs can easily be prevented (5). However, each year, a large number of medications are offered to the market, and as a result, interactions between medications are gradually increasing. For this reason, it is no longer practical for physicians to trust only to their knowledge in the prevention of PDDIs (6). Additionally, especially due to large number of patients visiting the primary health care facilities, limited examination time is allocated to each patient and consequently, the physicians are not adequately informed about the medication used by the patients. Thus, this leads to duplicated prescriptions and DDIs (7). To prevent this, there are certain computerized drug interaction checker programs; however, these are not sufficient alone since they can aid health professionals to reduce potential interactions only if they are integrated into the medical and practical knowledge of health professionals (6).

Although the importance of increased ADR risk caused by pediatric polypharmacy induced PDDI is widely accepted as in adult patients, research in this area is quite rare. The information obtained from such research will help physicians develop drug use habits for pediatric patients and will enable the design of safer systems for drug prescription ordering or subsequent drug follow-up $(8,9)$.

Non-steroidal anti-inflammatory drugs and antibiotics are the most frequently prescribed drug groups in primary care practices (6). Clarithromycin, a member of macrolide group, is a widely preferred antibiotic in the treatment of respiratory tract infections in children with a broad spectrum of antimicrobial activity, a relatively low rate of adverse events, and ease of dosing twice daily (10).

The aim of this study was to investigate the role of computerized drug interaction checker programs in the identification and prevention of PDDIs in clarithromycin prescribed pediatric outpatients.

\section{Methods}

This study was a retrospective observational prescription analysis held in Üsküdar-istanbul for a period of 12-month from January to December 2016. Pediatric outpatient clarithromycin prescriptions with a diagnosis of respiratory tract infection were collected from three different community pharmacies located around three different family medicine clinics.
The prescriptions were analyzed with respect to the medication (name and number) and the patient demographic data (gender and age). The active ingredients of the prescribed medications were determined and PDDIs were checked via R MediaPharma"database (GEMAŞ Corp., İzmir, Turkey) (11). For medications containing more than one active substance (for example combined cold medications), the analysis was performed for each active substance. The severity of PDDIs was classified according to Table 1 by the software program.

The local ethical committee approval was obtained for the study (Istanbul Medipol University Ethical Committee for Non-Interventional Clinical Investigations, dated: 18.01.2017, number: 01). Informed consent was not obtained in this study.

\section{Statistical Analysis}

Data were analyzed descriptively and presented as frequencies and percentages using SPSS version 21 (SPSS Inc., Chicago, IL, USA).

\section{Results}

A total of 100 prescriptions were examined and 51 of the prescriptions were written for patients between 0-2 years of age, 48 for 2-6 years of age and one for $6-18$ years of age. The distribution of prescriptions by age and gender is shown in Table 2.

In a total of 100 prescriptions, 266 different medications were prescribed by 52 different physicians. The mean number of medications per prescription was 2.66 11.11. In 44 of the prescriptions, there were more than 3 medications prescribed (Figure 1). The number of prescription-based medications was higher in the $0-2$ age group. From the prescriptions examined, a total of 16 PDDIs were identified, five of

\begin{tabular}{|c|c|}
\hline Severity & Explanation \\
\hline High & $\begin{array}{l}\text { The interaction between these drugs can be life } \\
\text { threatening or cause permanently damage. These } \\
\text { drugs are not usually used together, they require } \\
\text { medical intervention. An alternative medicine } \\
\text { should be used }\end{array}$ \\
\hline Moderate & $\begin{array}{l}\text { The clinical impact of interaction is limited, but } \\
\text { can be disturbing. Patient should be monitored } \\
\text { for the findings of interaction }\end{array}$ \\
\hline Low & $\begin{array}{l}\text { Interaction may occur depending on the } \\
\text { mechanism of action of co-administered drugs. } \\
\text { Caution should be taken with regard to the } \\
\text { reduced or increased efficacy related to the } \\
\text { combined drugs }\end{array}$ \\
\hline
\end{tabular}

Table 2. Distribution of prescriptions by age and gender

\begin{tabular}{|l|l|l|l|}
\hline \multirow{2}{*}{ Age, years } & \multicolumn{2}{|l|}{ Number of prescription $(\mathbf{n})$} & \\
& Female & Male & Total \\
\hline $0-2$ & $23(45 \%)$ & $28(55 \%)$ & 51 \\
\hline $3-6$ & $17(35 \%)$ & $31(65 \%)$ & 48 \\
\hline $7-18$ & $0(0.0)$ & $1(100 \%)$ & 1 \\
\hline
\end{tabular}


which were clarithromycin-related (31.25\%) and 11 of them were nonclarithromycin-related (68.75\%). Of the PDDIs identified, $72.3 \%$ were in the same prescription and $27.7 \%$ were in different prescriptions. The active substances that were found to interact with clarithromycin in the R MediaPharma" program were lidocaine, metronidazole and sultamicillin. Of the total 5 prescriptions, 3 were lidocaine and 1 was metronidazole and sultamicillin (Table 3).

When PDDIs were examined on a severity basis, 10 out of 16 (62.5\%) were high-risk, two (12.5\%) were moderate and four (25\%) were low-risk. DDIs with clarithromycin were moderate with lidocaine, and low with metranidazole and sultamicillin (ampicillin/sulbactam) (Table 4).

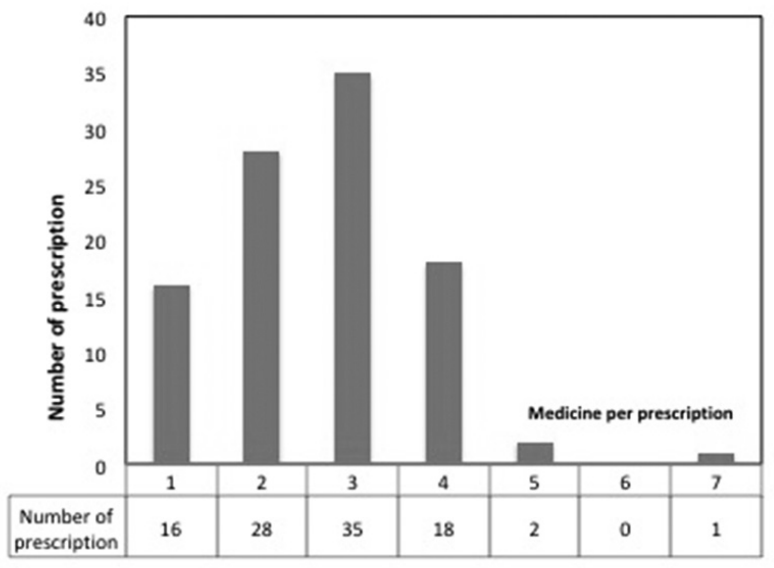

Figure 1. Distribution of medicines per prescription

Table 3. Classification of interaction with clarithromycin by R MediaPharma $_{x}$

\begin{tabular}{|l|l|l|l|}
\hline Active substance & $\begin{array}{l}\text { Number of } \\
\text { prescription }\end{array}$ & Severity & Possible result \\
\hline Lidocaine & 3 & High & $\begin{array}{l}\text { Prolongation of QT } \\
\text { interval, } \\
\text { Myocardial depression }\end{array}$ \\
\hline Metronidazole & 1 & Low & $\begin{array}{l}\text { Risk on the } \\
\text { prolongation of QT } \\
\text { interval }\end{array}$ \\
\hline Sultamicillin & 1 & Low & $\begin{array}{l}\text { Risk on reduction } \\
\text { in pharmacological } \\
\text { effect }\end{array}$ \\
\hline
\end{tabular}

Table 4. Distribution of potential drug-drug interactions according to the severity

\begin{tabular}{|l|l|l|l|l|}
\hline Severity & Age, years & & \\
\hline & $\mathbf{0 - 2}$ & $\mathbf{3 - 6}$ & $\mathbf{7 - 1 8}$ & Total \\
\hline Low & 2 & 2 & 0 & 4 \\
\hline Moderate & 2 & 0 & 0 & 2 \\
\hline High & 6 & 4 & 0 & 10 \\
\hline Total & 10 & 6 & 0 & 16 \\
\hline
\end{tabular}

\section{Discussion}

Drug interactions in multidrug use are a potential concern. Although comprehensive drug evaluations are effective, they are very labor intensive and costly. It is possible to avoid interaction and dose-related errors with integrated drug systems that health professionals could use in conjunction with medical and practical knowledge.

This study investigated the efficacy of drug interaction checker programs in the prevention of PDDIs with prescribed clarithromycin in pediatric patients. This group of patients was chosen for several reasons. First of all, this group of patients is more susceptible to medication errors. Additionally, the medical management of the pediatric patients presents unique challenges throughout the medication use process. Furthermore, studies with this group of patients are few in number (12). Macrolide group antibiotics is the most commonly prescribed group after penicillin in pediatric patients, and clarithromycin, one of the group members, is the most frequently prescribed active substance following erythromycin (13). DDIs induced Q-T prolongation with clarithromycin is the major concern despite the relatively low rate of adverse events (10). Although there are several checker programs (Micromedex", Lexicomp", Medscape ${ }^{*}, R_{x}$ MediaPharma" etc.) for the evaluation of PDDIs, owing to the price advantage, $\mathrm{R}_{\mathrm{x}}$ MediaPharma" is the most widely preferred program in the community pharmacies.

In this study, of the detected 16 PDDIs, five were clarithromycin-related (31.25\%) and 11 were non-clarithromycin-related (68.75\%). In the literature, the reported PDDI rate widely ranges between 19\% and 90\% (14-16). This difference might be due to the difficulties in conducting standardized prevalence studies in the area (17). The $16 \%$ rate reported in this study can be explained by the fact that the prescriptions were collected from a limited number of pharmacies that were relatively close in locations.

Studies show that PDDI rates vary depending on the healthcare centers that the patients refer to. While PDDI rate is $16 \%$ in emergency services, it is $70 \%$ in family medicine policlinics (18). Unlike previous study, however, the PPDI rate was found to be $16 \%$ in the present study. We should note here that although the prescriptions were collected from pharmacies located around the family medicine policlinics, they were collected only from three community pharmacies.

It is known that DDIs are proportional to the number of medications used concomitantly. Karas (19) reported a PPDI incidence of 5.6\% in patients using two different medications, $56 \%$ in patients using five different medications and $100 \%$ in patients using seven different medications. Similarly, Goldberg et al. (20) reported a PDDI prevalence of $13 \%$ for two medications and $80 \%$ for seven and above drug use. We also found that $72.3 \%$ of the interactions in our study were of the same prescription and that the incidence of PDDI increased with the increased number of medications per prescription. Among the prescriptions collected, there were more prescriptions for 0-2 age group patients, and the number of medications per prescription was high. We believe that physicians tend to prescribe more medications in this age group since these patients are unable to express themselves and parents are more prone to direct the physicians in assessing the symptoms. 
In our study, the majority of detected PDDIs ( $n=10,62.5 \%)$ were in highrisk category. It should be emphasized once again that the findings we obtained identify only PDDIs, because the database used in our study was insufficient to determine the clinical ADR (21). Similar previous studies showed that PDDI prevalence that may cause clinically significant ADRs is low despite the high prevalence of PDDI (22). According to Peng et al. (23), among the 2\% PDDIs identified by sophisticated DDI checker program, only $0.04 \%$ of the total prescriptions were clinically relevant DDIs which were identified by the combination of DDI checker program and clinical pharmacist review. On the other hand, it should be noted that ADRs may result in significant morbidity and mortality, and that the level of evidence for the severity of $62 \%$ of PDDIs is based on clinical practice $(24,25)$.

It is noteworthy that three of the five-clarithromycin-related interactions detected in our study were with lidocaine prescribed by different physicians. Both pharmacokinetics and pharmacodynamics interaction are seen with lidocaine. When given in combination with lidocaine, clarithromycin causes an increase the risk of ventricular arrhythmia by QT prolongation, on the other hand enhances the lidocaine effect/level by inhibiting the CYP3A4 enzyme (26). For this reason, patients should be monitored with electrocardiogram during treatment and motorization of serum lidocaine levels is suggested.

In our study, although the clarithromycin-to-metronidazole interaction was indicated as a low risk by the checker program, there are a few studies suggesting the prolongation of QT interval by metronidazole (27). Theoretically, co-administration of medications that can prolong QT interval may lead to an increased risk of ventricular arrhythmia, including torsade de pointes and sudden death. Although QT prolongation and ventricular arrhythmia were reported in patients treated with metronidazole in isolated studies, a causal relationship has not been established due to underlying conditions involved and concomitant medications in these studies (27).

The interaction with clarithromycin and sultamicillin (ampicillin/ sulbactam) was also classified as "low" in our study. Although some in vitro data indicate synergism between macrolides and penicillin, there are also some in vitro studies showing antagonism. Although data is available for erythromycin, this interaction may theoretically occur with other macrolides. According to the literature, there is no need to take any special precaution other than monitoring the effectiveness of treatment for this interaction (28-30).

Surveys show that $39 \%$ of medical errors occur during the prescribing process and $11 \%$ during the dispensing process (31). Tightening the control steps can significantly reduce DDIs and ARDs, which are important part of drug errors experienced during the prescribing procedure. Two important tools developed for this purpose are hospital information system and e-order system (32). With these systems, the physician can observe PDDIs and ADRs during prescribing procedure $(33,34)$. Still, the main problem with these systems is that patients do not always take their medical care from the same healthcare providers (35). Especially, in the Eastern cultures, it is common for patients to visit multiple hospitals with the same or similar conditions, and to change their doctors and/or hospitals $(36,37)$. There are studies showing that patients who receive medical care from different healthcare providers are more likely to suffer ADRs $(36,38)$. These systems are often designed for use in a single hospital or one managed care organization settings, and they do not have a common infrastructure for sharing the patient's medication history (34). For this reason, PDDI controls with these systems cannot go beyond hospital boundaries (39). Even though the computerized drug support and drug interaction checker programs have been developed to close this gap, the main issue with these programs is that they are standalone programs, which cannot be integrated into patient management systems. Therefore, for each check, physician should transfer data from the patient management system into DDI database and repeat this process for each prescribed medication (34). Especially in healthcare facilities with large number of outpatients, limited examination times of physicians is the biggest obstacle for the effective use of these programs. Consequently, prior to the initiation of treatment, the pharmacist, as the last ring of the healthcare chain in contact with the patient, is the final line of defense against harmful PDDIs (7).

Routine use of drug interaction checker programs in community pharmacies, which provide fast access, can help pharmacist for the prevention of vital malfunctions such as PDDIs. The use of these programs in combination with the medical and practical knowledge of health professionals could increase the quality and ensure the safety of the healthcare services offered.

\section{Study Limitations}

The basic limitation we should note here is that the prescriptions were collected from a limited number of community pharmacies. Despite the fact that 12 pharmacies were invited to take part in the study, six pharmacies did not agree to participate due to workload. What is more, during data collection process, three pharmacies that did not regularly provide prescriptions were excluded from the study. Therefore, a generalizability of the findings may be a limiting factor.

\section{Conclusion}

Computerized drug interaction checker programs with rapid access are not sufficient alone, but can help health professionals to prevent of PDDIs. The use of these programs, especially in community pharmacies, can serve for the identification of DDIs during delivery of the medicine to the patient. To ensure the effective use of the programs by health professionals, they need to be standardized to provide clinically relevant ADRs in line with evidence-based information, along with their integration into e-order systems. Hence, DDIs and ADRs caused by DDI during both prescribing and dispensing will be prevented more effectively.

Ethics Committee Approval: The local ethical committee approval was obtained for the study (Istanbul Medipol University Ethical Committee for Non-Interventional Clinical Investigations, dated: 18.01.2017, number: 01).

Informed Consent: Informed consent was not obtained in this study.

Peer-review: Externally peer-reviewed.

Author Contributions: Concept- Ş.A., T.N., M.C., B.B.; Design- Ş.A., T.N., M.C., B.B.; Supervision- M.C., B.B.; Resource- Ș.A., T.N., Materials- S..A., T.N., M.C., Data Collection and Processing- S.A., T.N., M.C., B.B.; Literature Search- \$.A., G.M.; Writing- \$.A.; G.M.; Critical Reviews- G.M. 
Conflict of Interest: No conflict of interest was declared by the authors.

Financial Disclosure: The authors declared that this study received no financial support.

\section{References}

1. Wyles H, Rehman HU. Inappropriate polypharmacy in the elderly. Eur J Intern Med 2005; 16: 311-3.

2. Edwards IR, Aronson JK. Adverse drug reactions: definitions, diagnosis, and management. The Lancet 2000; 35: 1255-9.

3. Pirmohamed M, James S, Meakin S, Green C, Scott AK, Walley TJ, et al. Adverse drug reactions as cause of admission to hospital: prospective analysis of 18 820 patients. BMJ 2004; 329: 15-9.

4. Lazarou J, Pomeranz BH, Corey PN. Incidence of adverse drug reactions in hospitalized patients: a meta-analysis of prospective studies. JAMA 1998; 279: 1200-5.

5. Dirim MM, Mousavi S, Tabrizian K, Afshari A, Ashrafi MH. Potential drugdrug interactions in prescriptions dispensed in community and hospital pharmacies in East of Iran. J Res Pharm Pract 2014; 3: 104-7.

6. Ansari J. Drug Interaction and Pharmacist. J Young Pharm 2010; 2: 326-31.

7. Abarca J, Malone D, Skrepnek G, Rehfeld R, Murphy J, Grizzle AJ, et al. Community pharmacy managers' perception of computerized drug-drug interaction alerts. J Am Pharm Assoc 2003; 46: 148-53.

8. Aagaard L, Christensen A, Hansen EH. Information about adverse drug reactions reported in children: a qualitative review of empirical studies. $\mathrm{Br}$ J Clin Pharmacol 2010; 70: 481-91.

9. Harper MB, Longhurst CA, McGuire TL, Tarrago R, Patterson A. Core Drug-drug interaction alerts for inclusion in pediatric electronic health records with computerized prescriber order entry. J Patient Saf 2014; 10: 59-63.

10. King SM. Claritromycin for children. Can J Infect Dis 1995; 6: 69-70.

11. GEMAŞ AŞ. RxMediaPharma ${ }^{\circledR}$ Interaktif Illaç Bilgi Kaynağı, https://www. eczanet.com/rxmediapharma (accessed January 1, 2017).

12. Benavides S, Huynh D, Brias L. Approach to the pediatric prescription in a community pharmacy. J Pediatr Pharmacol Ther 2011; 16: 298-307.

13. Clavenna A, Bonatti M. Differences in antibiotic prescribing in pediatric outpatients. Arch Disease Child 2011; 96: 590-5.

14. Reimche L, Forster AJ, van Walraven C. Incidence and contributors to potential drug-drug interactions in hospitalized patients. J Clin Pharmacol 2011; 51: 1043-50.

15. Straubhaar B, Krahenbuhl S, Schlienger RG. The prevalence of potential drugdrug interactions in patients with heart failure at hospital discharge. Drug Saf 2006; 29: 79-90.

16. Kliegman B, Nelson J.Textbook of Pediatrics, $17^{\text {th }}$ ed., Elsevier, Philadelphia, USA, 2003

17. Bigby $\mathrm{M}$, Jick S, Jick H, Arndt K. Drug-induced cutaneous reactions. A report from the Boston Collaborative Drug Surveillance Program on 15,438 consecutive inpatients, 1975 to 1982. JAMA 1986; 256: 3358-63.

18. Riechelmann RP, Zimmermann C, Chin SN, Wang L, O'Carroll A, Zarinehbaf S, et al. Potential drug interactions in cancer patients receiving supportive care exclusively. Journal Pain Symptom Manage 2008; 35: 535-43.

19. Karas S, Jr. The potential for drug interactions. Ann Emerg Med 1981; 10: 62730.

20. Goldberg RM, Mabee J, Chan L, Wong S. Drug-drug and drug-disease interactions in the ED: analysis of a high-risk population. Am J Emerg Med 1996; 14: 447-50.
21. Sarrazin MS, Rosenthal GE. Finding pure and simple truths with administrative data. JAMA 2012; 307: 1433-5.

22. Magro L, Moretti U, Leone R. Epidemiology and characteristics of adverse drug reactions caused by drug-drug interactions. Expert Opin Drug Saf 2012; 11 : 83-94.

23. Peng CC, Glassman PA, Marks IR, Fowler C, Castiglione B, Good CB. Retrospective drug utilization review: Incidence of clinically relevant potential drug-drug interactions in a large ambulatory population. J Manag Care Pharm 2003; 9: $513-22$.

24. Abarca J, Malone DC, Armstrong EP, Grizzle AJ, Hansten PD, Van Bergen $\mathrm{RC}$, et al. Concordance of severity ratings provided in four-drug interaction compendia. J Am Pharm Assoc 2004; 44: 136-41.

25. Fulda TR, Valuck RJ, Zanden JV, Parker S, Byrns PJ. Disagreement among drug compendia on inclusion and ratings of drug-drug interactions. Curr Ther Res 2000; 61: 540-8.

26. Aritmal Ampul Kısa Ürün Bilgisi (KUB) http://www.titck.gov.tr/KubKt/Index (accessed April 18, 2018).

27. Kounas SP, Letsas KP, Sideris A, Efraimidis M, Kardaras F. QT interval prolongation and torsades de pointes due to a coadministration of metronidazole and amiodarone. Pacing Clin Electrophysiol 2005; 28: 472-3.

28. Strom J. Penicillin and erythromycin singly and in combination in scarlatina therapy and the interference between them. Antibiot Chemother 1961; 11 : 694-7.

29. Cohn JR, Jungkind DL, Baker JS. In vitro antagonism by erythromycin of the bactericidal action of antimicrobial agents against common respiratory pathogens. Antimicrob Agents Chemother 1980; 18: 872-6.

30. Penn RL, Ward TT, Steigbigel RT. Effects of erythromycin in combination with penicillin, ampicillin, or gentamicin on the growth of listeria monocytogenes. Antimicrob Agents Chemother 1982; 22: 289-94.

31. Holdsworth, MT, Fichtl RE, Raisch DW, Hewryk A, Behta M, Mendez ER, et.al. Impacts of computerized prescribe order entry on the incidence of adverse drug events in pediatric patients. Pediatrics 2007; 120: 1058-66.

32. Fiumara K, Moniz T, Churchill WW. Case Study on the use of health care technology to improve medication safety In: Porché RA (Ed). Medication Use: A Systems Approach to Reducing Errors. Joint Commission Resources, USA, 2008, pp 103-14,

33. Bates DW, Leape LL, Cullen DJ, Laird N, Petersen LA, Teich JM. Effect of computerized provider order entry and a team intervention on prevention of serious medication errors. JAMA 1998; 280: 1311-6.

34. Kuperman GJ, Bobb A, Payne TH, Avery AJ, Gandhi TK, Burns G, et al. Medication-related clinical decision support in computerized provider order entry systems: A review. J Am Med Inform Assoc 2007; 14: 29-40.

35. Yeh YT, Hsu MH, Chen CY, Lo YS, Liu CT. Detection of potential drug-drug interactions for outpatients across hospitals. Int J Environ Res Public Health 2014; 11: 1369-83.

36. Chen TJ, Chou LF, Hwang SJ. Patterns of ambulatory care utilization in Taiwan. BMC Health Serv Res 2006; 6: 54-61.

37. Sato T, Takeichi M, Hara T, Koizumi S. Second opinion behaviour among Japanese primary care patients. Br J Gen Pract 1999; 49: 546-50.

38. Donkor ES, Quarcoo TPB, Nartey P, Agyeman IO. Self-Medication practices with antibiotics among tertiary level students in Accra, Ghana: A cross-sectional study. Int. J. Environ. Res. Public Health 2012; 9: 3519-29.

39. Hsu MH, Yeh YT, Chen CY, Liu CH, Liu CT. Online detection of potential duplicate medications and changes of physician behavior for outpatients visiting multiple hospitals using national health insurance smart cards in Taiwan. Int J Med Inform 2011; 80: 181-9. 